\title{
Ocena komisyjnego projektu nowelizacji ustawy o gospodarce nieruchomościami ${ }^{1}$
}

\begin{abstract}
Assessment of the committee's Bill on Amendment of the Act on Management of Real Estates: The author assesses that it is a legitimate intention to introduce into the legal system regulations providing for the possibility of an effective reaction of selfgovernment bodies to extreme cases of unjustified differentiation of the legal situation and, consequently, the financial one of individual owners of properties on which the adjacency fee is imposed. However, there are serious doubts as to the purposefulness of proceeding the bill, what results from a parallel legislative process, regarding a governmental bill which also covers the issue of the application of reliefs in connection with the imposition of an adjacency fee. The author points out that the legal means planned by the authors of the amendment are inappropriate with regard to the purpose of the statute, because they are connected to norms applied only in relation to civil law receivables, in a situation where the adjacency fee is strictly of a public law nature.
\end{abstract}

Keywords: real estate, regulatory impact assessment, bill Słowa kluczowe: nieruchomość, ocena skutków regulacji, projekt ustawy

\section{Zakres przedmiotowy ustawy}

Przedmiotem opiniowanego projektu jest wprowadzenie do systemu prawnego regulacji nowelizującej zapisy ustawy z 21 sierpnia 1997 r. o gospodarce nieruchomościami (t.j. Dz.U. 2018, poz. 2204, ze zm.; dalej: u.g.n.) przez dodanie nowego art. 148aa, zgodnie z którym, na zasadach określonych $\mathrm{w}$ art. 59 ustawy

Opinia prawna na temat komisyjnego projektu ustawy o zmianie ustawy o gospodarce nieruchomościami; Ocena skutków regulacji zawartych w komisyjnym projekcie ustawy o zmianie ustawy o gospodarce nieruchomościami (druk sejmowy nr 3345) sporządzona 8 kwietnia 2019 r. na zlecenie zastępcy Szefa Kancelarii Sejmu; BAS-WAP 594/19. 
z 27 sierpnia 2009 r. o finansach publicznych (t.j. Dz.U. 2017, poz. 2077, ze zm.), na wniosek właściciela nieruchomości:

- należności z tytułu opłaty adiacenckiej będą mogły być w całości lub w części umorzone,

- termin wniesienia opłaty adiacenckiej lub terminy wniesienia ratalnych opłat z tytułu opłaty adiacenckiej będą mogły być odraczane.

Projekt ustawy w zamierzeniu jej twórców stwarza realną możliwość reakcji władz w przypadkach, gdy stosowanie unormowań w aktualnym brzmieniu naruszałoby zasadę sprawiedliwości społecznej.

\section{Podmioty, na które oddziałuje akt}

Projekt dotyczy podmiotów, na które może zostać nałożona opłata adiacencka, tj. bliżej nieokreślony i trudny do oszacowania krąg osób fizycznych, osób prawnych oraz jednostek organizacyjnych nieposiadających osobowości prawnej (np. osobowe spółki handlowe) dysponujących nieruchomością, której wartość wzrosła wskutek budowy urządzeń infrastruktury technicznej z udziałem środków Skarbu Państwa, jednostek samorządu terytorialnego, środków pochodzących z budżetu Unii Europejskiej lub ze źródeł zagranicznych niepodlegających zwrotowi, albo na które nakładana jest opłata ustalona w związku ze scaleniem i podziałem nieruchomości, a także samym podziałem nieruchomości.

Proponowana regulacja będzie również oddziaływać na te jednostki samorządu terytorialnego, które zdecydują się na stosowanie ulg we wnoszeniu opłaty adiacenckiej przewidzianych w projekcie.

\section{Celowość wprowadzenia aktu}

Należy uznać, że pożądane i celowe jest wprowadzenie do systemu prawnego regulacji przewidujących możliwość skutecznej reakcji organów samorządu na skrajne przypadki nieuzasadnionego różnicowania sytuacji prawnej i w konsekwencji również finansowej poszczególnych właścicieli nieruchomości. Proponowane unormowania mogą bowiem stanowić swoisty „wentyl bezpieczeństwa” w tych przypadkach, w których nałożenie i bezwzględne wyegzekwowanie opłaty adiacenckiej pozostawałoby w rażącej sprzeczności z zasadami sprawiedliwości społecznej, mającymi swe źródło w treści art. 2 Konstytucji RP.

Należy się w pełni zgodzić z postulatem twórców nowelizacji w zakresie stworzenia możliwości jednakowego traktowania przez władze publiczne właścicieli nieruchomości bez względu na fakt, czy postępowanie w sprawie ustalenia opłaty adiacenckiej zostało wszczęte przed dniem 22 sierpnia 2017 r., czy też później. 
Na mocy przepisów przejściowych art. 4 ust. 3 ustawy z 20 lipca 2017 r. o zmianie ustawy o gospodarce nieruchomościami oraz niektórych innych ustaw (Dz.U. 2017, poz. 1509) przewidziano bowiem, że do postępowań dotyczących ustalenia opłaty adiacenckiej, które zostały wszczęte i niezakończone do dnia wejścia w życie ustawy nowelizującej, stosuje się przepisy dotychczasowe (przewidujące brak możliwości nałożenia opłaty w przypadku, gdy upłynęło 3 lata od dnia, w którym decyzja np. o podziale stała się ostateczna albo orzeczenie o podziale stało się prawomocne), natomiast w odniesieniu do pozostałych podmiotów obowiązek uiszczenia opłaty może nastąpić w skrajnych przypadkach również po wielu latach po wszczęciu postępowania (gdy decyzja nie jest wydawana w terminie).

Akceptując w pełni założenia, które legły u podstaw proponowanych rozwiązań, nie sposób jednak nie zauważyć, że istnieją poważne zastrzeżenia co do celowości wprowadzenia aktu w życie, które wynikają z toczącego się równolegle, jednak bardziej kompleksowego i jednocześnie zaawansowanego procesu legislacyjnego, obejmującego swym zakresem również zagadnienie dotyczące stosowania ulg w związku z nakładaniem opłaty adiacenckiej. Obecnie w Sejmie RP procedowany jest bowiem rządowy projekt ustawy o zmianie ustawy o Krajowym Zasobie Nieruchomości oraz niektórych innych ustaw (druk sejmowy nr 3364)2, który w art. 9 wprowadza zmiany m.in. w art. 98a, art. 107 i art. 148 u.g.n. idące w zbieżnym do zaproponowanego kierunku. Jak wskazują przy tym twórcy projektu rządowego, opłata adiacencka stanowi niepodatkową należność publicznoprawną, do której powinny znaleźć zastosowanie powszechnie akceptowalne instrumenty prawa finansów publicznych, dotyczące w szczególności ulg i zwolnień, a obowiązujące w ustawie o gospodarce nieruchomościami ulgi w zapłacie opłaty adiacenckiej (np. możliwość rozłożenia opłaty na raty) są mniej korzystne niż te wynikające $z$ ogólnych norm zawartych w ustawie o finansach publicznych (w szczególności jej art. 64). Uzasadnienie projektu rządowego wskazuje również na dostrzeżone w praktyce stosowania opłaty adiacenckiej negatywne skutki społeczne i poczucie niesprawiedliwości obywateli „dotkniętych” opłatą adiacencką, które mają zostać wyeliminowane przez nowelizację przewidującą, że organy wykonawcze gminy zostaną wyposażone w instrumenty pozwalające na eliminację lokalnych konfliktów i poczucia niesprawiedliwości społecznej.

\section{Planowane środki (narzędzia i działania) realizacji celów}

Środkiem do osiągnięcia celu projektu, tj. stworzenia mechanizmu umożliwiającego sprawiedliwe traktowanie wszystkich właścicieli obciążanych opłatą adiacencką ma być wprowadzenie do ustawy o gospodarce nieruchomościami regulacji, która w zakresie przyznawania ulg odsyła wprost do postanowień art. 59

2 Http://www.sejm.gov.pl/sejm8.nsf/druk.xsp?nr=3364) [dostęp 8 kwietnia 2019 r.]. 
ustawy o finansach publicznych (t.j. Dz.U. 2017, poz. 2077, ze zm.). Przywołany w projekcie art. 59 tej ustawy stanowi m.in., że w przypadkach uzasadnionych ważnym interesem dłużnika lub interesem publicznym należności pieniężne mające charakter cywilnoprawny, przypadające jednostce samorządu terytorialnego lub jej jednostkom organizacyjnym mogą być umarzane, terminy ich spłaty mogą zostać odroczone lub płatność tych należności może zostać rozłożona na raty, na zasadach określonych przez organ stanowiący jednostki samorządu terytorialnego, przy czym to organ stanowiący jednostki samorządu terytorialnego określa szczegółowe zasady, sposób i tryb udzielania ulg, warunki dopuszczalności pomocy publicznej w przypadkach, w których ulga stanowić będzie pomoc publiczną, oraz wskaże organ lub osobę uprawnione do udzielania tych ulg.

Jak wynika z powyższego, twórcy nowelizacji proponują w odniesieniu do ulg stosowanie unormowania dotyczącego wprost należności cywilnoprawnych. W związku z tym pojawia się zasadnicza wątpliwość koncentrująca się wokół tego, czy opłata adiacencka stanowi rzeczywiście należność ze sfery prawa prywatnego.

Biorąc pod uwagę całokształt charakteru prawnego instytucji opłaty adiacenckiej, uznać należy, że nie jest ona należnością cywilnoprawną, gdyż nie powstaje na podstawie stosunku cywilnoprawnego między gminą a zobowiązanym, ale obowiązek jej uiszczenia wynika bezpośrednio z mocy ustawy, w tym zwłaszcza z art. 144 ust. 1 u.g.n., zgodnie z którym właściciele nieruchomości uczestniczą w kosztach budowy urządzeń infrastruktury technicznej przez wnoszenie na rzecz gminy opłat adiacenckich. Wysokość tej opłaty ustalana jest w decyzji administracyjnej (art. 145, art. 146 u.g.n.), a nie w umowie zawartej pomiędzy stronami. $Z$ tego względu przepisy art. 59 ustawy o finansach publicznych, dotyczące ulg w spłacie należności cywilnoprawnych, nie powinny mieć zastosowania do opłaty adiacenckiej. Na fakt ów zwrócono również uwagę w orzecznictwie sądów administracyjnych ${ }^{3}$, w którym przesądzono o publicznoprawnym charakterze opłaty. Warto przy tym wskazać, że kwestie związane z ustaleniem tej opłaty i stosowaniem ulg w obecnych uwarunkowaniach prawnych uregulowane są bezpośrednio jedynie w ustawie o gospodarce nieruchomościami, której przepisy z zakresu prawa publicznego przewidują możliwość rozłożenia opłaty adiacenckiej na raty roczne płatne w okresie do 10 lat, co nastąpić może na wniosek właściciela nieruchomości (art. 147 ust. 1 u.g.n.). Powołana norma stanowi przepis szczególny w stosunku do ustawy o finansach publicznych, a jako taki ma on pierwszeństwo zastosowania przed przepisami ustawy o finansach publicznych, zgodnie z ogólną zasadą lex specialis derogat legi generali (prawo o większym stopniu szczegółowości pochodzące z aktów prawnych tej samej ran-

3 Zob. m.in. wyrok Wojewódzkiego Sądu Administracyjnego w Krakowie z 22 stycznia 2014 r., sygn. akt: II SA/Kr 1243/13, http://orzeczenia.nsa.gov.pl/doc/6FDA11DC44 [dostęp 8 kwietnia 2019 r.]. 
gi, np. z dwóch ustaw, obowiązujące w tym samym czasie, należy stosować przed prawem ogólniejszym).

Również w doktrynie prawa ${ }^{4}$ powszechnie przyjmuje się, że zasadniczymi cechami wyróżniającymi prawo cywilne i oparte na nim stosunki cywilnoprawne są: autonomiczność podmiotów rozumiana jako brak władczego podporządkowania podmiotów wchodzących ze sobą w określone stosunki prawne oraz brak bezpośredniego przymusu ze strony organów państwa. Metodzie cywilistycznej regulacji polegającej na zrównaniu pod względem prawnym pozycji stron w stosunku prawnym przeciwstawia się metoda administracyjna, polegająca na bezpośrednim władztwie i podporządkowaniu podmiotu prawa czy obowiązku organom państwowym czy samorządowym. Tymczasem źródłem obowiązku będącego przedmiotem opłaty adiacenckiej nie jest określone zdarzenie, z którym prawo cywilne łączy taki skutek, lecz władcze działanie organu administracyjnego oparte na przepisach ustawy o gospodarce nieruchomościami. Zatem wynikający stąd obowiązek ma charakter publicznoprawny a nie prywatnoprawny (cywilnoprawny). Nie zmienia tego fakt, iż materialnoprawną przesłanką wymierzenia opłaty adiacenckiej jest wzrost wartości nieruchomości zaistniały na skutek budowy urządzeń infrastruktury technicznej, a środki z niej uzyskane służą finansowaniu budowy tych urządzeń ${ }^{5}$.

Warto przy tym zauważyć, że w prawie finansowym za opłatę uważa się świadczenie pieniężne, zasadnicze, bezzwrotne, zabezpieczone przymusem państwa, zaliczane - wraz z podatkami - do wspólnej grupy świadczeń budżetowych zwanych daninami publicznymi. Niektóre z nich mają charakter rekompensujący straty, które wywołują czynności obciążone opłatą, np. opłaty z tytułu udziału w kosztach budowy urządzeń komunalnych, energetycznych czy gazowych ${ }^{6}$. Również w nauce prawa podatkowego przyjmuje się powszechnie, że opłata jest daniną publicznoprawną posiadającą te same cechy co podatek, różniącą się jednak od tego ostatniego cechą odpłatności ${ }^{7}$.

$\mathrm{W}$ rezultacie opłaty, $\mathrm{w}$ tym również adiacencka, są nakładane decyzjami administracyjnymi rozstrzygającymi indywidualne sprawy i, stanowiąc niepodatkową należność budżetową, mają charakter publicznoprawny, przymusowy, ogólny i bezzwrotny, a obowiązek ich wnoszenia ma związek z prowadzeniem działalności zgodnej z obowiązującym prawem ${ }^{8}$.

4 Zob. m.in. A. Stelmachowski, Wstęp do teorii prawa cywilnego, PWN, Warszawa 1984, s. 38

Zob. m.in. cytowany wyżej wyrok w sprawie o sygn. akt II SA/Kr 1243/13.

E. Ruśkowski, Finanse i prawo finansowe, Białystok 1994, s. 233-234.

B. Brzeziński, M. Kalinowski, M. Masterczak, A. Olesińska, Ordynacja podatkowa. Komentarz, Torun 2002, s. 10.

8 Zob. wyrok Wojewódzkiego Sądu Administracyjnego w Białymstoku z 11 maja 2004 r., sygn. akt: II SA/Bk 34/04, http://orzeczenia.nsa.gov.pl/doc/A4AC4C58BF [dostęp 8 kwietnia 2019 r.]. 
Biorąc pod uwagę wszystkie wskazane uwarunkowania, należy dojść do jednoznacznego wniosku, że planowane przez twórców nowelizacji środki prawne realizacji celów ustawy są niewłaściwe, bowiem łączą się z unormowaniami stosowanymi wyłącznie w odniesieniu do należności cywilnoprawnych, a opłata adiacencka ma charakter stricte publicznoprawny.

\section{Ocena kosztów i korzyści}

\section{Ocena skutków prawnych}

Projekt zawiera unormowania, które pod względem formalnym nie wywołują istotnych wątpliwości, bowiem zasadniczo zapewniona została przejrzystość regulacji, jej zrozumiałość, kompleksowość oraz systemowość. Projekt nie budzi również zastrzeżeń w zakresie prawnych skutków materialnych, bowiem prawidłowo wyznaczono reguły wejścia w życie ustawy.

Niemniej ustawa wywołuje pewne obiekcje formalne $\mathrm{z}$ uwagi na fakt, że postanowienia jej art. 1 nie uwzględniają systematyki ustawy o gospodarce nieruchomościami. Projekt zakłada bowiem dodanie w ustawie o gospodarce nieruchomościami bezpośrednio po art. 147 nowego art. 148aa, w sytuacji gdy obowiązuje jeszcze art. 148 u.g.n. Dlatego też postuluje się - celem zapewnienia wyższego stopnia czytelności regulacji - zmodyfikowanie treści przepisu w drodze prawidłowego wskazania miejsca zamieszczenia nowego unormowania po art. 148, a nie po art. 147 u.g.n.

\section{Ocena kosztów i korzyści finansowych i administracyjno- -organizacyjnych}

Należy zgodzić się z założeniami twórców nowelizacji, że wprowadzane regulacje nie będą miały istotnego wpływu na finanse publiczne, którego nie można jednak precyzyjnie określić ze względu na dużą liczbę zmiennych czynników wpływających na postępowanie władz gmin. Warto przy tym dodać, że biorąc po uwagę stosunkowo niewielki udział opłat adiacenckich w dochodach jednostek samorządu terytorialnego oraz fakultatywność proponowanego systemu udzielania ulg przez organy, zasadne jest przyjęcie stanowiska zakładającego niski poziom zarówno kosztów, jak i korzyści finansowych oraz organizacyjno-prawnych nowego rozwiązania.

\section{Podsumowanie}

Uwzględniając ogół uwarunkowań związanych z proponowaną regulacją, uznać należy, że cel opiniowanego projektu zostanie zrealizowany w drodze wprowadzenia systemu umożliwiającego jednostkom samorządu terytorialnego sto- 
sowanie mechanizmu ulg w uiszczaniu opłaty adiacenckiej, który może przyczynić się do skuteczniejszej realizacji konstytucyjnej zasady sprawiedliwości społecznej oraz do niwelowania zbędnych napięć społecznych, wynikających z powszechnego wśród osób zobowiązanych do uiszczenia opłaty adiacenckiej poczucia „nierównego traktowania” ich przez prawo.

Wdrożenie analizowanych regulacji wymaga jednak właściwego sposobu formułowania przepisów, które będzie uwzględniało kluczowy fakt, iż opłata adiacencka ma charakter publicznoprawny, a nie - jak założyli twórcy nowelizacji cywilnoprawny.

Projekt ustawy winien również uwzględniać systematykę ustawy o gospodarce nieruchomościami. Sformułowanie treści normatywnej projektu nie uwzględnia systematyki ustawy o gospodarce nieruchomościami, bowiem przewiduje dodanie bezpośrednio po art. 147 u.g.n. nowego art. 148aa w sytuacji, gdy obowiązuje jeszcze art. 148 u.g.n.

Istnieją jednak poważne zastrzeżenia co do celowości wprowadzenia opiniowanego aktu w życie, które wynikają z toczącego się równolegle z inicjatywy rządowej, jednak bardziej kompleksowego i jednocześnie zaawansowanego procesu legislacyjnego, obejmującego zakresem również zagadnienie dotyczące stosowania ulg w związku z nakładaniem opłaty adiacenckiej.

\section{Bibliografia}

Brzeziński B., Kalinowski M., Masterczak M., Olesińska A., Ordynacja podatkowa. Komentarz, Toruń 2002.

Ruśkowski E., Finanse i prawo finansowe, Białystok 1994.

Stelmachowski A., Wstęp do teorii prawa cywilnego, Warszawa 1984. 